\title{
Influence of Employee value Proposition on Employer Brand
}

\author{
Ankita Dhamija Nagpal, Gaurav Nagpal
}

\begin{abstract}
Now days, Organizations are facing employees attraction challenges to poach the best talent in their industry. Every organization is not ready to good pay bundles to their employees. To retain the efficient human resource $(H R)$ with right abilities, acquaintance, understanding, caliber which help the organizations to achieve their objectives in effective and efficient way. Employee value Proposition (EVP) is the concept which helps the organizations to magnetize, maintain and preserve the best endowment. In this research paper, researcher tried to create a relationship between the employee value proposition and Employer branding. This research is proposed to have descriptive research design. We have created a model specifying the connection between the employer brand and the components of EVP.
\end{abstract}

Keywords : Employer branding, Employee value proposition, human resource, connection

\section{INTRODUCTION}

$\mathrm{I}_{\mathrm{n}}$ assets of an organization but also as the parthers in their created by the employer with his long term efforts, nor is it a term used for the sake of standard, inclination in the industry rather it is an effort made by every employee. To retain the efficient human resource with right abilities, acquaintance, understanding, caliber that help the organizations to achieve their objectives in effective and efficient way.

\section{A.Employee Value Proposition:}

Employee value Proposition is defined as a lay down the benefits to an employee achieves as a result of his efforts, skills, knowledge, experience, capabilities that he provides to an organization. These are the benefits that attract, retain and allow the employees to survive and grow in an organisation. Employer promises to provide the best of the opportunities, experience and working environment which suits the employees of the organisation which in turn, it helps the employer to attract best of the talent from the potential employees. This also helps the employer to expand and develop his business in international markets. Employee value Proposition allows the employees to share their personal objectives which support the human resource department to ensure the efficient realization of the individual and professional objectives of the employees.

Revised Manuscript Received on October 31, 2019.

* Correspondence Author Management Sciences, New Delhi, India.Email: ankitadhamija@gmail.com

Gaurav Nagpal*, Research Scholar, BITS, Pilani, India. Email: gaurav19821@gmail.com business. Employer Branding is not a mere brand which is

Ankita Dhamija Nagpal*, Lingaya's Lalita Devi Institute of

EVP is a silent and unwritten agreement among the talented employees and employer about the facilities and the benefits to be provided to the potential employees. This agreement is mutually agreed among talented employees and employer at the time of selection process. This is a psychological contract which attract smart personality employees with high involvement attribute to the prospective employer.

A sound employee value proposition motivate the employees to perform better, which results in better organization turnover and reduces the employee turnover. EVP is always promoted in organizations as strategic tactic to improve organization productivity and efficiency.

\section{B.An employer attracts employees based on following parameters of EVP}

- Better Work culture with good team atmosphere

- Decentralized decision making

- Reward benefits

- The correct blend of authority and responsibility

- Attractive pay packages and perks offered by Employer(pay progression is aligned with career progression)

- Career enhancement should be there with growth and development

- Creativity and Learning in Job profile and in other areas

- Opportunities for job enrichment ,job enlargement and job rotation

Now, having discussion on EVP, let's talk about employer brand, Employer Brand states that creating a positive representation of the employer among existing and perspective the employee's . The concept of Employer Brand is at its evolutionary stage. Any organization can improve the brand image by winning the "war for talent" by attaining best of the employees from labor market. An employee centered EVP to poach the best talent based on environment, strategies and need of the organization.

Similar to the way the product brand shows the loyalty of customer towards a particular product. The employer brand also shows the loyalty of employees towards a particular employer which in turn helps in reducing attrition rate

If employees are satisfied with the employer brand, they are ready to adapt themselves as per the expectations and needs of the employer. But it is important to note that that creating an employer brand is not a one day process rather it takes years for employees to know, understand and experience the employer and from the brand image. People create the brand of the organization throughout the employee life cycle. 


\section{Influence of Employee value Proposition on Employer Brand}

Now, let's discuss how employer branding positively influence the HR function in an organisation

- Influence of Brand on stakeholders(customer loyalty, quality product)

- Improve commitment of new hires(new innovation, efficiency, employee engagement which will b meaningful, safe)

- Employees act as advocate( due to transparent performance management brings skills, eagerness and entrepreneurship to fruitful results )

- Help the Human Resource Department in winning the Talented Employees

- Employee Engagement(enroll, socialize, retain)-seriousness, well being and accessibility

- Employee Attraction

- Employee Procurement

- Employee retention(employee relation, tailored work arrangement)

- Work Economic Situation(skill deficiency, unemployment)

The solid and well settled employer helps in creating competitive advantage in hunting the best talent in the endowment market starts through better EVP.

The major problem is that EVP is designed as per the employer convenience but it needs to be aligned with employee preference. It need to be understood by HR Managers that the talent and skills of the employees has to be measured, based on which they should design the effective EVP with the change in the content of EVP within the approved budget for HR department . This research helps in bringing about the change more productive and sustainable work culture which offers sustain employee engagement.
C. Five Steps Involved In EVP Development
- Analyse
- Design
- Communicate
- Integrate
- Measure

\section{LITERATURE REVIEW}

Albeit numerous studies (Eshiteti et al,2013[1]; Maluti, 2012; Mokaya, 2008; Waititu, 2010; Bula, 2012) has been focused on different aspects of employee value proposition like employee attraction, maintenance, responsibility and how to persuade staff. There is not much of literature study on connection between EVP and employee magnetism, maintenance and engagement. There is only observation and self reported study on degree on talent wars in which main focus on the value of EVP to divert the work market towards a particular organization. So the study looks at the positive effects of EVP implementation on employee magnetism, continuation and commitment. [1][2]

Employee Value Proposition is basically the combination of different features that the labor market and human resources observe as the worth which increases throughout the effort they plant in the organization (Corporate Leadership Council Research, 2006)[3].EVP is the homogeny of benefits and encouragement, learning and experience by an employee in their career path which shows why the whole life job knowledge is considered as superior to at some other organization and it is must for different organizations to retain and attract the talented work force (Hill and Tande, 2006)[4]. EVP is basically the give and take relationship between the employee and employer. It includes the each and every benefit that an employer gives in return of the work experience that the employee achieves in fulfilling the organization's objectives.

There are many organization up till now to analyze the significance of have solid EVP incorporating in their system for attracting and convincing the talented work force in the labor market. It becomes feasible for the organizations to attract the talent from more intense section of the employment market (Corporate Leadership Council, 2012) [5].

Ambler and Barrow (1996), in their study, they analyzed 27 organizations and conducted the semi organized indepth interview which defended the helpfulness of employer branding in human resource management. The researcher concluded that the employees working in the environment have supplementary learning in deconstructing any exchange of the organization. These have made them heads of disbeliefs with regards to the run of the mill procession of interior changes in the communications and instrument. They reason that branding has relevant inside of the setting of employment. [6]

Moroko and Uncles (2009), analyzed and examined the different system in which the different parameters were studied and gives proper shape to employer branding which support the sustainability of employer branding procedure also. Diverse parameters have been optional in the employer branding literature in view of Setting up of standards. [7] SHRM's review in 2008 analyzed and found that $61 \%$ of organizations covered are focusing on an employer brand, and $25 \%$ were in process of either creating or wanting to do so in upcoming 12 months (Society for Human Resource Management,SHRM, 2008).[8]

Dawn and Biswas (2010), analyzed the concept of employer branding studied how Indian employers with an affirmative commercial notion can magnetize and preserve talented employees. It also focused on enlighten the importance and the suitability of consequence and building an effective employer branding tactic of Indian organizations. An successful employer brand is important for escalating competitive improvement which support the Indian employers to develop their organizations in positive notion and revaluate their organizations.[9]

Every organization should grow and consider the Employee value proposition and employer branding together. The work power mastermind, carrying out examination, competency mapping, and capacity assertion should done effectively.

Employer branding is a latest approach toward hiring the finest human talent within mentioned situation that finish up enthusiastically vigorously. Employer branding is worn to represent how organizations support their proposal to budding and existing employees discuss with them and stay at their promises "progressing both inside and outside the firm, a sensible point of view of which attract the employees towards as an employer and makes the employee to choose the employer" (Backaus and Tikoo, 2004, p. 120).[10] 
Sullivan (2004) states that employer branding insisted on expected method to arrangement with the icon of human resource, potential human resource, and related stakeholders as to a particular firm.[11]

Armstrong (2006) insisted upon employer branding to create such an image of the organization in labor market for prospective human resource which will be influenced by the bad name of the business or administrations of the organization and in addition its ill repute for being an human resource.[12]

Ritson (2002) state that organizations having strong employer brands need to spend less on outlay of human resource retention, improves human relations, human resource procurement and even offer less salaries for same talented employees to organizations who are unable to create a better employer brands.[13]

Gatewood et al. (1993) analyzed that organization's reputation is a major indicator of selection to look after completion of tenure with the organization having employer brands, a major part of the association with employment[14]. Brand conviction be the relation that a employer has to a brand (Aaker, 1991). [15]

Slope and Tande (2006) states that Employee Value Proposition is "the give and the get" relationship between organization and employees, unite each part of the job knowledge from the organization's basic targets and principles; to careers, to its stakeholders; to the full arrangement of total rewards system'

Human recourse enlargement opportunities will be given equal importance as highly during applying as during safeguarding, as will future professional opening and esteem as per Employment Value Proposition - Corporate Leadership Council (CLC) Research Summary 2006.[16]

Every organization runs smoothly on the basis of their human assets. It is very indispensable to have effective manpower planning. It is crucial to have right person at right job at right time. So to retain the best talent in the organization there is a need for Employee value proposition. EVP should be tailor made as per the capabilities and talent of the employees. It is the EVP which satisfy the employee's different need which are described in Hertzberg's Two-Factor Theory. In this motivational theory, employee feels motivated to be effective and productive due to hygiene factors like status, job safety and security, better salary, increments, fringe benefits, work environment, paid insurance, paid leaves which should be included in employee value proposition. There are other motivational factors performance of employee, recognition, appreciation, job designation, responsibility and growth opportunities for which make the employee satisfied but these hygiene factors plays a very important role in both the aspects i.e not only on motivating the employees but before that an employee should feel satisfied.

\section{REVIEW CRITERIA}

- To create a model that can capture the relationship between the EVP and Employer Branding

\section{RESEARCH METHODOLOGY}

This research is proposed to have descriptive research design. We will create a model specifying the connection between the employer brand and the components of EVP
$E V P=\left[\sum_{i=1}^{m} a i H i+\sum_{j=1}^{n} b j M_{j}\right] \mathrm{Nx} \mathrm{Ty}+\alpha$

where

ai (for $\mathrm{i}=1$ to $\mathrm{m}$ ) are coefficients of hygiene factors $\mathrm{Hi}$

bj (for $\mathrm{j}=1$ to $n$ ) are coefficients of motivation factors $\mathrm{Mj}$

$\mathrm{N}=$ number of employees

$\mathrm{T}=$ average age of employees in the organization

$\mathrm{x}$ is the employee strength exponent

$\mathrm{y}$ is the employee age exponent

$\alpha$ is the random error

\section{FEW EXAMPLES FROM CORPORATE WHO ARE PROMOTING EVP IN THEIR ORGANIZATIONS}

1. TCS: Tata Consultancy Service (TCS) gives international exposure to their employees which includes clip away at better ventures to work on. Flexibility at work which includes different angles to the corporate culture with innovation ideas. This gives the better situation to the human resources to examine their own space/region to analyse their hidden talent which they best fit into to maintain Work life balance.

2. PWD: Public Work Department (PWD) is one of the best organization who provide the special organization's profession site which incorporates a 'People's online journal ' where employee can include organization events, their articles, upcoming events etc.

3. Google: The World's Most Attractive Employers award was begged by Google in 2013 among the business classification. (Source: The universium). Employer branding was created by Google by best of services provided to customer, access data, advancement given in product services, building customer administration brilliance and versatility to their employees and budding hires. Employer branding are practiced at Google as they are continuously working in confidence with prospective growth, sustain research for betterment of customers, specialized discussions with experts, empower mind's eye. Google likewise have TIFG (Thanks Google Its Friday) program for employees which support Google to create employer's brand effectively. (Nasscom 2006)

4. Microsoft: Microsoft adds on advantage is that they give priority to ladies employees. Microsoft empowers the women staff. They have a diverse Facebook page for 'Ladies Special at Microsoft,' which is just concerning about ladies discussions and is famous as their professions page.

5. Pepsico: Pepsico always offer gifts to their customer. Benefits on products and services from the best brands are usually offered in the competitive world. Pepsico always compensate holiday travel and housing would fall into this group, whether it is related to a staff motivation or acknowledgment scheme or not. There is prerequisite of munchies such as cold drinks, coffee, cheese platters and fruit in the workplace would also fall into this category. 


\section{Influence of Employee value Proposition on Employer Brand}

\section{OBSERVATION}

- EVP directly influence productivity

- EVP directly influence employee loyalty

- EVP is give and get relationship

- EVP is an umbrella that ensures the overall consistency of employer communication

\section{CONCLUSION}

Now days, organizations are trying their best to create the employer brand as a part of strategic planning by providing the best of the facilities to their employees. These steps are taken by the organizations to make sure that their employees remain focused and loyal towards their organization. So this model will help to create a better employee value proposition which in result will create a positive notional employer brand. This model will even help the organizations to motivate their employees also.

\section{REFERENCES}

1. Eshiteti S, Okaka, O., Maragia, S., Odera, O. and Akerele, E. (2013). Effects of Succession Planning Programs on Staff Retention. Mediterranean Journal of Sciences

2. Bula, H. (2012). Labor Turnover in the Sugar Industry in Kenya. European Journal of Business and Management. 4(9)

3. Corporate Leadership Council Research. (2006). Employment Value Proposition Survey.

4. Hill, B \& Tande, C 2006, Total Rewards: the Employee Value Proposition, workspan, October, viewed 17 December 2010, http://www.tandehill.com/pdfs/Total-Rewards.pdf

5. Corporate Leadership Council Research. (2012). Employment Value Proposition Survey

6. Ambler, T. \& Barrow, S. (1996). The Employer Brand. Journal of Brand Management.4. The Employment Value Proposition - A Key to Attraction and Commitment 2006,

7. Moroko \& Uncles (2009)Employer Branding and Market Segmentation. Journal of Brand Management Palgrave Macmillan 1350-23IX Vol. 17, 3, 181-196

8. Society for Human Resource Management,SHRM, 2008

9. Dawn, S.K. and Biswas, S. (2010), Employer Branding: A New Strategic Dimension of Indian Corporations, Asian Journal of Management Research, Special issue No. 1, pp.21-33, Paper presented at International Conference on People Management: Issues \& Challenges, Organised by Jyotirmoy School of Business, http://www.ipublishing.co.in/ajmrvol1no1/sped12011/ AJMRSP1003.pdf, Accessed on January 17, 2012.

10. Backhaus, K, \&Tikoo. S., (2004). Conceptualizing and researching employer branding. Career Development International, 9(5), 501-517.

11. Sullivan, Dr. John, 2004. :The 8 Elements of a Successful Employment Brand. New York: John Sullivan.

12. Armstrong,M.(2006),In A Handbook of Human Resource Management Practice, 10 Edition,Kogan Page Ltd.,London

13. Ritson, M. (2002), "Marketing and HE collaborate to harness employer brand power", Marketing, 24 October, p. 24

14. Gatewood, R.D., Gowan, M.A. and Lautenschlager, G.J. (1993), "Corporate image, recruitment image, and initial job choice decisions", Academy of Management Journal, Vol. 36, pp. $414-427$.

15. Aaker DA. Managing Brand Equity: Capitalizing on the Value of a Brand Name. The Free Press, New York, NY, 1991.

16. Employment Value Proposition-Corporate Leadership Council(CLC)Research Summery 2006,NC Office of STATE Personnel ,viewed 17December 2010 https://clc.executiveboard.com/Public/PDF/Attracting_and_Retaining_ Critical_Talent_Segments_Exec_Summ.pdf

\section{AUTHORS PROFILE}

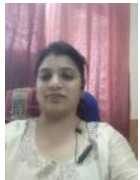

Dr. Ankita Nagpal is Associate Professor at LLDIMS New Delhi. Her area of research interest is Human Resource Management, Manpower Planning, Employer Branding, Gender justice and diversity at the workplace, etc. She is PhD. MBA, M.Com. and UGC NET Qualified. She has also done a programme in HR Analytics from IIM Rohtak, and a faculty development programme from IIM Rohtak. She carries with her around twelve years of industry experience and teaching experience, combined together. She have 35 research publications in the best of journals and conference proceedings. She has on her name the best paper awards. She has a membership of NHRDN. She is in the panel of PhD Evaluators panel of many universities of India

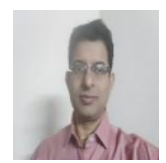

Gaurav Nagpal is an Assistant Professor in Management Department of Birla Institute of Technology and Science Pilani. His area of expertise is Operations and Supply Chain Management, Operations Research, Industria Engineering, Business Statistics and Data Analytics. He received his Bachelor's degree in Mechanical Engineering from YMCA Institute of Engineering in 2005. Post that, he completed his MBA from Indian Institute of Foreign Trade, New Delhi. He has been a GATE topper with 99.83 percentile (AIR-41) in mechanical engineering. He has also done EPMBD from IIM Calcutta, and is CSCP qualified from APICS. He is currently pursuing his $\mathrm{PhD}$ from BITS Pilani in the area of inventory management.

He has twelve years of industry experience, of which the former seven years were into Operations and supply chain roles with NTPC, Daimler India Commercial Vehicles and with Escorts Agri-machinery Group. After that he worked for five years in business strategy, planning and analysis profiles. Before joining BITS Pilani as Assistant Professor in 2018, he served the leading grocery e-Commerce firm "Grofers India Private Limited" in the capacity of Associate Director- Business Planning and Analysis. 